\title{
Hip Dislocation
}

National Cancer Institute

\section{Source}

National Cancer Institute. Hip Dislocation. NCI Thesaurus. Code C34698.

A cong enital or traumatic abnormality in which the femoral head slips out of the acetabulum. 